render it without regret, and should gladly welcome a destructive criticism of Mr. Culverwell's argument.

I have had some conversation with Sir Robert Ball on this subject, and I find that he is not as yet disposed to change his opinion. He contends that, when we bear in mind that it is in the tropics that the great oceanic currents get their warmth, we should admit that the change in the daily supply of heat by onefifth part is competent to produce a great change in northern climates. Whilst I think that he would not now lay much stress on the quantitative results derived from the supposed temperature of space, he would still maintain that the cause is adequate to the effect. But does not this bring us nearly back to Croll's point of view, and demand a discussion of the effect of diminished or increased sun-heat on oceanic circulation?

December 16, I 895 .

[At the request of the Editor, one sentence has been erased from the original letter.]

\section{Barisal Guns.}

WiTh reference to Prof. Darwin's letter in Nature of October 3I, I 895, relative to Barisal Guns, I enclose a communication, which I received from an observer familiar with the phenomenon. Medical College, Lahore.

D. G. F. GRan'.

I first heard the Barisal Guns in December 1871 , on my way to Assam from Calcutta through the Sunderbans. The weather was clear and calm, no sign of any storms. All day the noises on board the steamer prevented other sounds from being heard ; but when all was silent at night, and we were moored in one or other of the narrow channels in the neighbourhood of Barisal, Morelgunge and upwards, far from any villages or other habitations, with miles and miles of long grass jungle on every side, the only sounds the lap of the water or the splash of earth, falling into the water along the banks, then at intervals, irregularly, would be heard the dull muffled boom as of distant cannon. Sometimes a single report, at others two, three, or more in succession; never near, always distant, but not always equally distant. Sometimes the reports would resemble cannon from two rather widely separated opposing forces, at others from different directions but apparently always from the southward, that is seaward. We were not very far from the sea when I first heard them, and on mentioning to an old lady on board that I heard distant cannon, she first told me of the mysterious sounds known as the "Barisal Guns." For the next two years I was in Upper.Assam, above Groalpara, and do not remember ever hearing them there; but in I874 I was working in the Goalpara district in the tract south of Dhubri, between the Brahmaputra and the Garo Hills; sometimes near the river, sometimes near the foot of the hills, at others between the two. I gradually worked down as far as Chilmari Ghât (I think it is called), the landing-place for Tura, the headquarters of the Garo Hills district, and distant quite 300 miles from the mouths of the Brahmaputra and Ganges. The villages are few and far between and very small, firearms were scarce, and certainly there were no cannon in the neighbourhood, and fireworks were not known to the people. I think I am right in saying I heard the reports every night while south of Dhubri, and often during the day. The weather on the whole was fine. Short, sharp " nor'westers" occasionally burst on us of an evening, with much thunder and lightning; but the days were clear, and, as a rule, the sounds were heard more distinctly on clear days and nights.

I specially remember spending a quiet Sunday, in the month of May, with a friend at Chilmari, near the river-bank. We had both remarked the reports the night before and when near the hills previously. About ro a.m. in the day, weather clear and calm, we were walking quietly up and down near the riverbank, discussing the sounds, when we heard the booming distinctly, about as loud as heavy cannon would sound on a quiet day about ten miles off, down the river. Shortly after we heard a heavy boom very much nearer, still south. Suddenly we heard two quick successive reports, more like horse-pistol or musket (not rifle) shots close by. I thought they sounded in the air about I 50 yards due west of us over the water. My friend thought they sounded north of us. We ran to the bank, and asked our boatmen, moored below, if they heard them, and if so in what direction. They pointed south!

As we often did with boatmen, we asked these their opinion of the sounds. They said they heard them at all seasons and in every direction all up the river from Serajgunge to Dhubritheir beat; that they were in the air, and came from the gods NO. I 366 , VOI. 53$]$
(Deota) celebrating the continuous marriage of the Ganges (the goddess Ganga) with the Brahmaputra (son of Brahma); that they were heard in their fathers' time, and long before. We could elicit nothing further from them or others.

The year previous I had discussed the sounds with Captain Stewart, of the Survey of India Department, who had some years previously been employed on the Survey of the Sunderbans tracts. He said the reports were heard all over the Sunderbans; that several experts had failed to account for them. He once had a theory that they were caused by submarine eruptions in the Bay of Bengal; but this would hardly account for them 300 miles distant, and I believe they are never heard out at sea in the bay.

I have heard planters (who have heard them near the hills where bamboo jungles abound) say that they were merely reports caused by bamboos bursting in jungle fires. But they are heard far from all bamboo jungles, and in the absence of jungle fires.

Strange to say, I next heard the reports when crossing the Mahanadi River, between Purnea and Kishengunge in the old road from Sahebgunge to Darjeeling.

The time was about ten at night, the evening close, hot, and very cloudy, but no thunder anywhere. The booming sounded some miles away. There are no cannon anywhere in the neighbourhood, nor any large cities where possibly fireworks might be in progress. The year after $\mathrm{I}$ heard them again at the same place; on this occasion the sky was clear and starry, the time between 3 and 4 a.m., the booming distant but very distinct.

I have no theory. I fancy the sounds must be purely electric, but certainly have nothing to do with clouds, nor with cannon, nor fireworks, nor jungle fires.

If I can answer any other questions on the subject, I will be pleased to do so ; but I think I have told you all I know.

G. B. ScotT.

\section{Remarkable Sounds.}

I HAVE this day received from the Rev. W. S. Smith, Congational Minister of Antrim, Ireland, the following account of natural sounds connected in some way with Lough Neagh. The details are so interesting that $I$ send them as a contribution to your present correspondence on natural sounds.

Highgate, N., December 19, I895.

C. Tomlinson.

Lough Neagh is a sheet of water covering an area of upwards of 150 square miles, with very gradually receding shores, excepting at one or two spots. For many years after my settlement as minister here from England, I heard at intervals, when near the lake, cannon-like sounds ; but not being acquainted with the geography of the distant shores, or the location of towns, or possible employments carried on, I passively concluded that the reports proceeded from quarrying operations, or, on fine summer days, from festive gatherings in Co. Derry, or Co. Tyrone. In time I came to understand that it was not from the opposite shores, but from the lake itself that the sounds proceeded. After questioning many of the local residents, I extended my inquiries to the fishermen, but they could assign no cause. A strange thing about the matter is that the people generally knew nothing of the phenomenon, and that it is shrouded in mystery. I have heard the sounds during the whole year. ... I have heard the reports probably twenty times during the present year, the last being on a Sunday afternoon a month since, when I heard two explosions; but with two exceptions they have all seemed to come from many miles away, from different directions at different times. They have come apparently from Toome Bay, from the middle of the lake, and from Langford Lodge Point, about nine miles distant. A fisherman thought they must be the result of confined air that reached the lake by means of springs that are believed to rise here and there in the bottom. But the lake is shallow, seldom more than 45 feet deep. The depression now covered by the lake having been caused, it is believed, by volcanic action when the trap-rock of Co. Antrim was erupted, there may possibly be subterranean passages, though I confess their occurrence does not seem very probable; while the sounds emanate, as stated, from various parts of the lake. I have as yet spoken to no one who observed any movement of the waters when explosions took place, nor have I spoken to any one who was close to the spot at the time. Rather every one seems to have heard them only in the distance, which is strange, as fishermen are on the lake during many months in the year, at all hours of the day and night. 